\title{
Seasonal Dispersal in Non-Cyclic Populations of Clethrionomys glareolus and Apodemus flavicollis
}

\author{
Joanna GLIWICZ
}

Gliwicz J., 1988: Seasonal dispersal in non-cyclic populations of Clethrionomys glareolus and Apodemus flavicollis. Acta theriol., 33, 18: 263-272 [With 3 Tables \& 3 Figs.]

Dispersal was studied in stable (non-cyclic) populations of Clethrionomys glareolus (Schreber, 1780) and Apodemus flavicollis (Melchior, 1834 ) by the removal grid method. The seasonal pattern of dispersal consisted of two distinct "waves": spring - early summer and autumn dispersers. Sex ratio and percentage distribution of adult, subadult and juvenile individuals among dispersers and in the control population were found to differ. During the breeding season a higher proportion of subadult females was found among C. glareolus dispersers, and of subadult males among $A$. flavicollis dispersers, than on the control grid. The dispersal rate correlated well with population growth rate during the breeding season. It has been suggested that tendencies to disperse and the population growth are both governed by breeding activity, which changes during the breeding season. Charasteristics of autumn dispersers differed between the two species; in C. glareolus they were mostly very young individuals, probably ousted from the dense autumn population, whereas in A. flavicollis they accurately reflected the composition of the control population, and could be seasonal migrants to winter habitats.

[Department of Wildlife Management, Agricultural University of Warsaw, Rakowiecka 26/30, 02-528 Warsaw, Poland]

\section{INTRODUCTION}

Since the early seventies dispersal has become one of the central problems in small mammals population ecology. Much has already been written about its evolution, adaptive value, role in density regulation, and possible role as a driving force of the rodent density cycles (e.g. Krebs \& Myers, 1974; Lidicker, 1975; Łomnicki, 1978; Stenseth, 1983; Bondrup-Nielsen, 1985). With theoretical models and speculations highly developed, there is still a great need for empirical studies conducted on a variety of species to confirm or disprove hypotheses and generalizations offered by theory.

The present study deals with dispersal in non-cyclic populations of Clethrionomys glareolus (Schreber, 1780) and Apodemus flavicollis (Melchior, 1834) sharing the same forest habitat, where their densities were realatively stable from year to year and varied only seasonally. 
This gave the opportunity to compare seasonal dispersal behaviour in two rodent species, which differ in respect to many population characteristics.

\section{STUDY AREA, METHODS \& MATERIAL}

The study was carried out in a suburban forest (Mlociny Wood) situated on the outskirts of Warsaw. Study area was located in a Carici elongatae - Alnetum forest association. For a more detailed description of the area and its vegetation see Gliwicz (1981). The rodent community consisted of three species: Clethrionomys glareolus, Apodemus flavicollis and A. agrarius (Pallas, 1771). An extensive trapping carried out in the neighbourhood of the study area in 1975-78 showed that the density of rodents in the habitat was relatively stable from year to year (R. Andrzejewski and co-workers, unpubl.). The present study of dispersal carried out in 1977 involved only two former species, the third - A. agrarius was left unmanipulated. Dispersal was investigated by the removal grid method (Krebs et al., 1976; Gaines \& McClenaghan, 1980).

The experimental design consisted of two 1 ha grids (control and removal), situated $0.6 \mathrm{~km}$ apart. On each grid there were 49 live trap stations (each with two traps), $15 \mathrm{~m}$ apart. In the control grid, trapping was carried out five times for 7 nights at $6-7$ week intervals, from April to October. All individuals caught were marked by toe clipping and released at the place of capture. From the experimental grid all $C$. glareolus and A. flavicollis were removed in April, and animals caught later were treated as incoming dispersers and successively removed from the plot. In addition to the regular trapping carried out at the same time as on the control grid, the traps on the removal grid were set every two weeks for 1-2 nights for more frequent removal of rodents, in order to keep the experimental "dispersal sink" as empty as possible, and to prevent prolonged settlement of dispersers. Weight and reproductive condition, such as testes position, open or closed vagina, pregnancy or lactation were recorded for each captured animal.

The distance between the two grids prevented the animals from the control plot to disperse onto the removal grid (individuals marked on the former were never recaptured on the latter). Therefore, the density of the control population was not affected by the presence of an empty area.

In April, when residents were still present on the removal grid, the dispersers could not be distinguished. From May on, dispersers caught during each trapping session were considered to represent dispersal tendency occuring in the population between two consecutive sessions. Dispersers caught during additional trappings between the regular sessions, were pooled with those caught during the next regular session. Data for May represented late spring, about one month after the beginning of the breeding season. Data for July showed summer situation when reproduction and maturation rates were still high. Data collected in September, the last month of the breeding season, represented late summer, and October data were collected after ceasation of breeding.

A total of $177 \mathrm{C}$. glareolus and $124 \mathrm{~A}$. flavicollis were caught on both grids during the study period. On the removal plot $48 \mathrm{C}$. glareolus and $60 \mathrm{~A}$. flavicollis dispersers were found. The number of dispersers caught during each trapping, 
as well as the number of individuals caught at the same time in the control population are presented in Table 1 . Since the material available was not always sufficient for statistical calculation, some trends could not be proved statistically.

\section{RESULTS}

\subsection{Seasonality of Dispersal}

A ratio of the number of dispersers caught on the removal grid to the number of individuals present on the control grid at the same time, gives the dispersal rate of the population during the period between consecutive trapping sessions (Krebs, et. al., 1976). These rates are often calculated per week to account for some discrepancies in the duration

Table 1

Numbers of dispersers caught on the removal grid, numbers of individuals present on the control grid, and dispersal rate calculated as a ratio of these two numbers.

\begin{tabular}{lrrrrr}
\hline Individuals & April & May & July & Sept. & Oct. \\
\hline & \multicolumn{1}{c}{ C. glareolus } & & & \\
Dispersers & - & 25 & 14 & 3 & 6 \\
Control population & 18 & 36 & 40 & 21 & 14 \\
Dispersal rate & & 0.69 & 0.35 & 0.14 & 0.43 \\
& \multicolumn{1}{c}{ A. flavicollis } & & & \\
Dispersers & - & 17 & 27 & 5 & 11 \\
Control population & 2 & 12 & 19 & 19 & 12 \\
Dispersal rate & & 1.42 & 1.40 & 0.26 & 0.92 \\
\hline
\end{tabular}

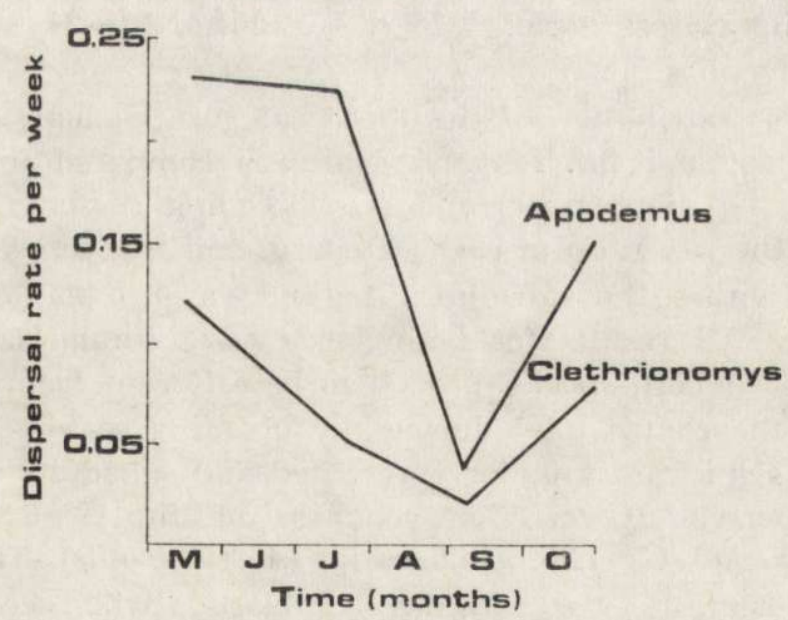

Fig. 1. Seasonal changes in rates of dispersal of Clethrionomys glareolus and Apodemus flavicollis. The dispersal rates as in Table 1, but recalculated pery week of period between consecutive trapping sessions. 
of perioc's between trappings, and to make them comparable to results of other studies. In this study, since the intertrapping periods were almost equal, both measures are appropriate and are used alternatively

For both species, the dispersal rates varied seasonally (Table 1). The numbers of dispersers of both species observed in different months of the study period were significantly different from the numbers expected, assuming a stable proportion of dispersers in the population $\left(\chi^{2}=10.32\right.$, $d f=3, p<0.05$ for $C$. glareolus, and $\chi^{2}=19.45, d f=3, p<0.01$ for A. flavicollis).

The emerging seasonal pattern indicated two distinct waves of dispersal, one in spring and early summer, the second in autumn, after the breeding season (Fig. 1). The two waves of increased dispersal were evident in both species and they seem to be common among other rodents (see Gliwicz, in press, for review).

\subsection{Composition of Dispersers}

A comparison between individuals caught on the control grid and the removal grid was made, in order to determine whether the dispersers represented a random or biased sample of the studied populations.

Three weight classes, corresponding to age/breeding status categories were distinguished. For C. glareolus the classes were as follows: $\geqslant 20 \mathrm{~g}-$ adult individuals, all sexually mature; $15-19 \mathrm{~g}$ - subadults, some mature, others still immature at the same body weight; $\leqslant 14 \mathrm{~g}-$ juveniles, all immature, still in juvenile pelage. For A. flavicollis the corresponding classes were: $\geqslant 25 \mathrm{~g}$ - adults, $18-24$ - subadults, and $\leqslant 17 \mathrm{~g}$ - juveniles.

Percentage distribution of the three categories among animals caught on the control and the removal grid was compared for the breeding season (May - September) and post-breeding season (October) separately. Also the sex ratio in each category, and the percentage of mature individuals within the subadult category was compared between grids and seasons. All results for both species are summarized in Table 2.

Dispersers of both species proved to be different from the individuals present on the control plot during the breeding season. In both species adult were significantly underrepresented and subadults overrepresented among dispersers ( $G$-test for goodness of fit, $G=6.30, p<0.05$ for C. glareolus and $G=7.25, p<0.05$ for A. flavicollis). The sex ratio of subadult dispersers was significantly biased, when compared to the control subadults: in C. glareolus in favour of females $\left(\chi^{2}=17.50, p<0.01\right)$ whereas in $A$. flavicollis in favour of males $\left(\chi^{2}=10.07, p<0.01\right)$. Significantly more immature individuals were found among subadult dispersers 
than among subadult individuals on the control grid $\left(\chi^{2}=9.14\right.$ for C. glareolus and 41.60 for A. flavicollis).

Though all the differences between the dispersers and the control individuals had the same direction during the entire breeding season, they were most evident in July. Therefore the data for July were chosen for more detailed presentation of the biased characteristic of the breeding-season dispersers (Fig. 2).

Table 2

Attributes of dispersers caught during the breeding and the postbreeding seasons in relation to the attributes of the control individuals. The statements "more" and "less" indicate significant differences between the groups.

\begin{tabular}{|c|c|c|c|c|}
\hline Species & Age & $\begin{array}{l}\text { Percentage } \\
\text { inds. }\end{array}$ & Sex ratio & $\begin{array}{l}\text { Immature } \\
\text { among } \\
\text { adults }\end{array}$ \\
\hline \multicolumn{5}{|c|}{ Breeding season (May - September) } \\
\hline C. glareolus & $\begin{array}{l}\text { adult } \\
\text { subadult } \\
\text { juvenile }\end{array}$ & $\begin{array}{l}\text { less } \\
\text { more } \\
\text { less }\end{array}$ & $\begin{array}{c}\text { as in control } \\
\text { more } 00 \\
\text { more } \$+\end{array}$ & more \\
\hline A. flavicollis & $\begin{array}{l}\text { adult } \\
\text { subadult } \\
\text { juvenile }\end{array}$ & $\begin{array}{l}\text { less } \\
\text { more } \\
\text { more }\end{array}$ & $\begin{array}{c}\text { as in control } \\
\text { more } \text { ch }^{-} \\
\text {more ô ô }\end{array}$ & more \\
\hline \multicolumn{5}{|c|}{ Post-breeding season (October) } \\
\hline C. glareolus & $\begin{array}{l}\text { adult } \\
\text { subadult } \\
\text { juvenile }\end{array}$ & $\begin{array}{l}\text { less } \\
\text { less } \\
\text { more }\end{array}$ & $\begin{array}{l}\text { as in control } \\
\text { as in control } \\
\text { as in control }\end{array}$ & \\
\hline A. flavicollis & $\begin{array}{l}\text { adult } \\
\text { subadult } \\
\text { juvenile }\end{array}$ & $\begin{array}{l}\text { as in control } \\
\text { as in control } \\
\text { as in control }\end{array}$ & $\begin{array}{l}\text { as in control } \\
\text { as in control } \\
\text { as in control }\end{array}$ & \\
\hline
\end{tabular}
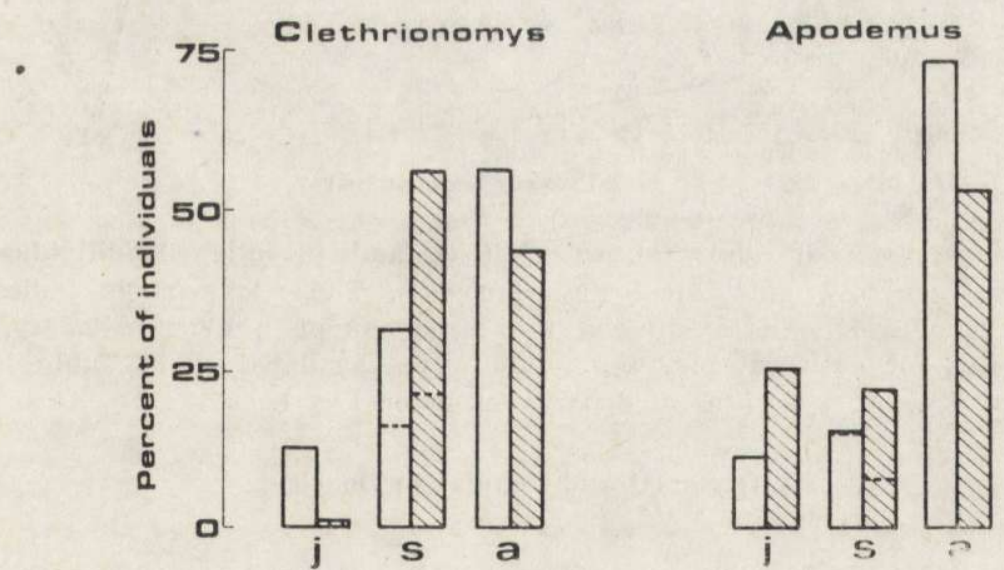

Fig. 2. Percentage of adult (a), subadult (s) and juveniles. (j) individuals in the control population (open bars) and among dispersers (hatched bars) in July. Bars for subadults are divided to indicate mature (lower) and immature (upper) individuals. 
Autumn dispersers (October) were different than the breeding season ones (Table 2). In $C$. glareolus 5 out of 6 dispersers were juveniles. (Though the total number of the dispersers was very low, the observed proportion of juveniles to older individuals, $5: 1$ or $83 \%$, was nearly reverse to that expected from the distribution on the control plot, about $2: 4$ or $36 \%$ ). In A. flavicollis the autumn dispersers reflected accurately the structure of the control population. All age categories and both sexes were in the same proportions on the removal and on the control plot.

Dispersal rates, calculated for different months for adult, subadults and juveniles separately, as a ratio of numbers of these individuals among dispersers to their numbers in the control population at the same time, illustrate well the different dispersal tendencies among the three categories. They also reflect the change in rodent dispersal between the breeding and the post-breeding season (Fig. 3).

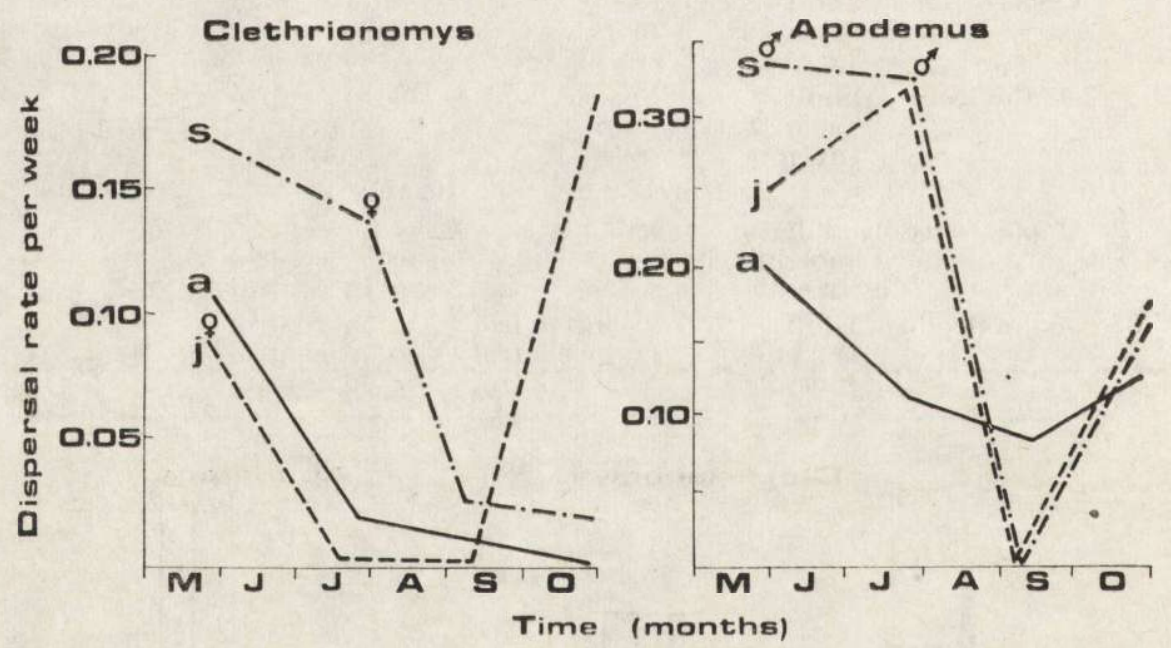

Fig. 3. Dispersal rates of adult (a), subadult (s) and juvenile (j) individuals of Clethrionomys glareolus and Apodemus flavicollis. The sex symbols indicate a significant surplus of one sex among the dispersers of a given category. The dispersal rates for each category separately were calculated as in Table 1 , and are presented per week as on Fig. 1.

\subsection{Dispersal and Population Density}

In the literature dealing with dispersal a strong controversy exist about the relationship between population density and dispersal (see Gaines \& McCleneghan, 1980; Stenseth, 1983, for review). To find the relationship between the two variables in the studied populations, the 
dispersal rates observed during the breeding season (May-September) were plotted against the densities of the control population. No significant correlation was found between the two values, and for A. flavicollis the correlation coefficient was negative (Table 3).

However, when the dispersal rates were plotted against the density increase rates observed in the control population, high positive correlations were found for both species (although only for C. glareolus was the correlation significant). The positive correlation between dispersal rate and population growth suggests that the two variables are both effects of a common cause.

Table 3

Correlation coefficients $(r)$ between rates of dispersal occurring in the breeding season (May-September) and density of the control population; and between these rates and density growth rates of the control population.

\begin{tabular}{lclcc}
\hline Correlation & C. glareolus & \multicolumn{2}{c}{ A.flavicollis } \\
\hline $\begin{array}{l}\text { between dispersal rate } \\
\text { and density }\end{array}$ & $0.65 \mathrm{~ns}$ & $-0.51 \mathrm{~ns}$ \\
$\begin{array}{l}\text { between dispersal rate } \\
\text { and density growth rate }\end{array}$ & $0.98 *$ & $0.73 \mathrm{~ns}$ \\
\hline
\end{tabular}

ns - non-significant, ${ }^{*} p<0.05$.

\section{DISCUSSION}

The dispersal occurring in the two species during the breeding season seems to be a movement of subadult individuals looking for a new place to mature and reproduce. The factors which force the adolescent individuals to leave their home area and become dispersers have been discussed in length (see Gaines \& McClenagham, 1980, for review). According to one theory, it may be caused by the territorial behaviour of mature individuals (Bondrup-Nielsén, 1985). The spatial interactions within the populations may indeed be directly responsible for the observed dispersal, and possible differences in the spacing behaviour of the two species should be considered as a cause for observed interspecific differences in the dispersers.

The spatial organization of C. glareolus is based on territoriality of mature females. An exclusive breeding territory is a prerequisite for female maturation (Bujalska, 1970). This is why the bank vole dispersers consist primarily of immature females. Much less is known about social/ spatial organization in Apodemus. It probably varies between species of the genus. According to Wolton and Flowerdew (1985) A. sylvaticus 
(Linnaeus, 1758) females are territorial and males hold overlapping home ranges. According to Bujalska (1981) in A. agrarius populations both males and females are territorial. As to A. flavicollis, there are no conclusive data on the spatial behaviour of the species, though from my unpublished data it seems to be similar to that of Peromyscus maniculatus (Wagner, 1845), where males are territorial (Howard, 1949; Fairbrain, 1978), with several females living within one male territory (Mihok, 1979). The same pattern of spatial organization was suggested by some authors for A. sylvaticus (Brown, 1969; Cody, 1982). Male territoriality would explain the male biased sex ratio found among subadult and juvenile dispersers of $A$. flavicollis. Young males in order to establish their own breeding territories may have to disperse.

The positive correlation between dispersal rate and the population increase rate was found to be quite common in rodents, especially in cyclic populations during the increase phase (Stenseth, 1983). Animals leaving their populations before a peak density is reached were defined by Lidicker (1975) as presaturation dispersers. The correlation found here for seasonal dispersers of voles and mice leaving their home areas during the breeding season, suggests that they are also presaturation dispersers. The common cause affecting both variables, the rate of density increase and the rate of dispersal, may be a breeding activity of animals.

At the beginning of the breeding season, when the density is low, the breeding activity is high. The fitness of an individual is increased by reproducing immediately rather than postponing reproduction (Stenseth, 1983), and therefore rodents are highly physiologically motivated to mature and reproduce. In effect, (1) the population grows rapidly, and (2) subadult animals are highly motivated to find breeding territories, mature and reproduce. If they fail to do so in a local area, they disperse. Later in the season (August-September), the breeding activity is supressed (animals are physiologically less stimulated to mature and to reproduce). This results in both a decreased population growth rate and no motivation for subadults to leave home populations.

The autumn dispersal seems to be different in each of the studied species. In C. glareolus almost all autumn dispersers were juveniles (see also Kozakiewicz, 1976). It is difficult to imagine what these young individuals could gain from leaving familiar areas just before the approaching winter. These were probably low rank individuals ousted from the dense autumn population; and if so, they may be considered the saturation dispersers (Lidicker, 1975). In A. flavicollis, on the other hand, the autumn dispersers represented a large random fraction of the local population, and they could be moving to a new habitat for winter. 
Muridae are known for their low site tenancy and seasonal migrations (Viitala \& Hoffmeyer, 1985), and, therefore, the yellow-necked mice caught in October on the removal grid were most probably the seasonal migrants.

Acknowledgements: I would like to thank Dr. N. Ch. Stenseth and anonymous reviewers for their critical reading of an earlier draft and for suggesting many improvements. The work was partly supported by the grant CPBP 04.10.02.

\section{REFERENCES}

1. Bondrup-Nielsen S., 1985: An evaluation of the effects of space use and habitat patterns on dispersal of small mammals. Ann. Zool. Fennici, 22: 373-384.

2. Brown L. E., 1969: Field experiments on the movements of Apodemus sylvaticus L. using trapping and tracking techniques. Oecologia, 2: 198-222.

3. Bujalska G., 1970: Reproduction stabilizing elements in an island population of Clethrionomys glareolus (Schreber, 1780). Acta theriol., 15: 381-412.

4. Bujalska G., 1981: Reproduction strategies in populations of Microtus arvalis (Pall), and Apodemus agrarius (Pall.) inhabiting farmaland. Pol. ecol. Stud., 7: $229-243$.

5. Cody C. B. J., 1982: Studies on behavioural and territorial factors relating to the dynamics of woodland rodent populations. D. Phil. thesis. University of Oxford.

6. Fairbrain D. J., 1978: Dispersal in deer mice, Peromyscus maniculatus: proximal causes and effects on fitness. Oecologia, 32: 171-193.

7. Gaines M. S. \& McClenaghan L. R. Jr., 1980: Dispersal in small mammals Ann. Rev. Ecol. Syst., 11: 163-195.

8. Gliwicz J., 1981: Competetive interactions within a forest rodent community in central Poland. Oikos, 37: 353-362.

9. Gliwicz J., (in press): Patterns of dispersal in non-cyclic populations of small rodents. [In: "Animal dispersal - small mammals as a model”, Eds. N. Ch. Stenseth \& W. Z. Lidicker]. Chapman \& Hall. London.

10. Howard W. E., 1949: Dispersal, amount of inbreeding, and longevity in a local population of prairie deer mouse on the George Reserve, Southern Michigan. Contrib. Lab. Verteb. Biol. Univ. Mich., 43: 1-50.

11. Kozakiewicz M., 1976: Migratory tendencies in a population of bank voles and description of migrants. Acta theriol., 21: 321-338.

12. Krebs C. J. \& Myers J. H., 1974. Population cycles in small mammals. Advan. Ecol. Res., 8: 268-399.

13. Krebs C. J., Wintage J., LeDuc J., Redfield J. A., Tait H. \& Hilborn R., 1976. Microtus population biology: dispersal in fluctuating populations of $M$. townsendii. Can. J. Zool., 54: 79-95.

14. Lidicker W. Z. Jr., 1975: The role of dispersal in the demography of small mammals. [In: "Small mammals: their productivity and population dynamics", Eds. F. B. Golley, K. Petrusewicz \& L. Ryszkowski]. Cambridge Univ. Press., 5: $103-128$.

15. Lomnicki A., 1978: Individual differences between animals and the natural regulation of their numbers. J. Anim. Ecol., 47: 461-475. 
16. Mihok S., 1979: Behavioral structure and demography of subarctic Clethrionomys gapperi and Peromyscus maniculatus. Can. J. Zool., 57: 1520-1535.

17. Stenseth N. Ch. 1983: Causes and consequences of dispersal in small mammals [In: "The ecology of animal movement", Eds. I. R. Swingland \& P. J. Grenwood] pp. 63-101. Clarendon Press. Oxford.

18. Viitala J. \& Hoffmeyer I., 1985: Social organization in Clethrionomys compared with Microtus and Apodemus: social odours, chemistry and biological effects. Ann. Zool. Fennici, 22: 359-371.

19. Wolton R. J. \& Flowerdew J. R., 1985: Spatial distribution and movements of wood mice, yellow-necked mice and bank voles. [In: "The ecology of bank voles and wood mice", Eds. J. F. Flowerdew, J. Grunell \& J. H. W. Gipps]. Symp. zool. Soc. Lond., 55: 249-275. Oxford Univ. Press. Oxford.

Received 12 October 1987, Accepted 19 January 1988.

\section{Joanna GLIWICZ}

SEZONOWE ZMIANY TENDENCJI MIGRACYJNYCH W NIECYKLICZNYCH POPULACJACH CLETHRIONOMYS GLAREOLUS I APODEMUS FLAVICOLLIS

\section{Streszczenie}

Zbadano migracyjność w populacjach nornicy rudej i myszy leśnej w okresie kwiecień-październik 1977, przeprowadzając eksperyment terenowy na 2 powierzchniach 1-hektarowych. Na jednej pozostawiono caly zespól gryzoni (kontrola), a $\mathrm{z}$ drugiej $\mathrm{w}$ kwietniu usunięto osobniki badanych gatunków, a następnie usuwano osobniki nachodzące, traktując je jako migranty. Tendencje migracyjne (= migracyjność) w populacjach mierzono stosunkiem liczby migrantów do liczby osobników obecnych na powierzchni kontrolnej w tym samym czasie (Tabela 1).

Stwierdzono występowanie 2 okresów wzmożonej migracji: wczesnoletni i jesienny, po zakończeniu rozrodu (Ryc. 1). Osobniki migrujące w każdym z tych okresów różniły się od siebie. Wczesnoletnie migranty, w porównaniu z populacją kontrolną, charakteryzowały się dużym udziałem osobników dojrzewających płci terytorialnej (Tabela 2, Ryc. 2 i 3). Migracyjność w okresie rozrodczym byla skorelowana $\mathrm{z}$ tempem zmian liczebności populacji (Tabela 3), co sugeruje, że ten sam czynnik odpowiedzialny jest za zmiany liczebności i migracyjności. Czynnikiem tym może być aktywność rozrodcza (wysoka na początku i zmniejszająca się w II połowie sezonu), która sprawia, że osobniki dojrzewające szybko wczesnym latem, fizjologicznie stymulowane do jak najszybszego przystąpienia do rozrodu usiłują wczesnym latem założyć własne areały, a gdy nie znajdują miejsca w lokalnej populacji, migrują.

Jesienią migranty nornicy to najmłodsze osobniki, a skład wiekowy i płciowy migrantów myszy leśnej jest taki sam jak w populacji kontrolnej. Sugeruje to, że jesienna migracja ma inne przyczyny i charakter $\mathrm{u}$ każdego $\mathrm{z}$ badanych gatunków. 